\title{
Feigned Weakness, False Happiness, Pretended Submission and Other Tricks of the Heroines of the Russian Epos
}

\author{
Inna Veselova iD http://orcid.org/0000-0002-6479-8491 \\ Russian Literature Department \\ Philological Faculty \\ St. Petersburg State University \\ e-mail: veselinna@mail.ru
}

\begin{abstract}
This article is based on study of the tricksters' tricks played by the heroines of the Russian epos known as bylinas. Variants of bylina plots with female protagonists have been contemplated, taking into consideration the concept by Michel de Certeau of two modes of practices - tactic and strategic - and James Scott's concept of "the weapons of the weak." The narrator informs the audience first about the modi operandi under various circumstances, and second about the underlying values governing the choice of this or that modus operandi. Systematic studies of variants of bylina plots confirm the fact that the narrators pay a lot of attention to the personality, appearance and agency of epic heroines. The cunning tricks, daring deceptions, bold choices and exceptional physical fortitude of the heroines surprise the singers of the tales. The activities of female characters are analyzed in the social context. The story-telling is a method of teaching modes and ways of real-life behavior. The bylinas 'singers are rendering their personal experience and knowledge in fictionalized form.
\end{abstract}

Keywords: tricksters' tricks, Russian epos, bylinas, female characters, collective ethos, patriarchal family, the singer

Słowa kluczowe: sztuczki tricksterów, rosyjskie eposy, byliny, postaci kobiece, etos zbiorowy, rodzina patriarchalna, pieśniarz

This article is based on my study of the tricksters' tricks played by the heroines of the Russian epos known as the bylinas. Variants of bylina plots with female protagonists have been contemplated taking into consideration Michel de Certeau's ${ }^{1}$ concept of

\footnotetext{
${ }^{1}$ M. de Certeau, The Practice of Everyday Life, Berkeley 1984.
} 
two modes of practices, tactic and strategic, and James Scott's ${ }^{2}$ concept of "the weapons of the weak." Both de Certeau and Scott are of the opinion that the tactic mode of practice (or resistance by means of "the weapons of the weak") involves "trickster's tricks." Hereinafter this term refers to a character's action described by Elena S. Novik in the article The Structure of Fairy Tale Trick as containing the following three elements: the trickster's awareness of the antagonist's interests, the trickster's manipulation of such interests for his own ends, and the trickster provoking the antagonist to actions beneficial to the trickster. ${ }^{3}$

In the course of two centuries of study of the Russian epos, the female characters of the Russian bylinas have been commonly considered as inseparably linked with the male protagonists. Only at the end of the 20th century and the beginning of the 21 st have several ethnographic, historical, and later folklore, studies dedicated specifically to feminine epic heroines been published. ${ }^{4}$ In the introduction to her thesis about female warriors of the Russian epos, Elena L. Madlevskaya states that very few authors have completely left dazzling and picturesque female heroines out of the scope of their attention, although "as a rule the figure of a female warrior is described in academic literature strictly in the context of the masculine hero's fate." ${ }^{5}$

The tables of contents of all known collections of bylinas confirm the fact that throughout the whole history of publications of the Russian epos, the publishers name variants of bylina after the name of the hero without no reference to the heroine, even if the latter is the actual driving force of the bylina's plot. For example, in the bylina "Mikhailo Potyk" the events are triggered by the hero's relations with his fiancé, later wife, later rival, Marya Lebed Belaya (Marya the White Swan), but her name is never mentioned in the plot attribution. In bylinas' titles where the name of the bogatyr (the hero) is followed by the name of a heroine ("Dobrynia and Marinka," "Dobrynia and Nastassya," "Churila and Ekaterina"), such reference only helps to classify the plot type in the series of other plots within the cycle dedicated to a particular male protagonist (such as "Dobrynia and Alyosha," "Alyosha Popovitch and Tugarin"). The female characters are also quite inconspicuous in adaptations of folk themes for theater, cinema, literature and the visual arts. The artists and scriptwriters of feature

2 J. Scott, Weapons of the Weak: Everyday Forms of Peasant Resistance, New Haven 1985.

3 'First, the trickster's game takes into consideration the antagonist's point of view, his interests, aims and ways to do things. [...] In other words, the trick is a successful when and if it meets in some aspects not only the trickster's interests, but the interests of his antagonist. [...] Second, any trickster's actions are in fact tactical moves: the trickster either overstates his abilities in the antagonist's eyes or understates his potential danger. And third, the kernel of any trick is provocation. Any deceits and simulations regardless of their tactics are aimed to make the antagonist act in a way which is beneficial for the trickster, so the trickster is using the antagonist to reach the objective desired by the trickster." E.S. Novik, Struktura skazochnogo tryuka, [in:] Ot mifa k literature. Sbornik v chest'75-letiya E.M. Meletinskogo, Moscow 1993, pp. 145-160.

${ }^{4}$ N.L. Pushkareva, Chastnaya zhizn' russkoj zhenshchiny: nevesta, zhena, lyubovnica ( $X-$ nachalo XIX v.), Moscow 1997; E.L. Madlevskaya, Geroinya-voitel'nica v ehpicheskih zhanrah russkogo fol'klora [avtoreferat dissertacii kandidata filologicheskih nauk, St. Petersburg 2000], manuscript in Russian National Library; L.J. Olson, S. Adonyeva, The Worlds of Russian Village Women: Tradition, Transgression, Compromise, Madison 2013.

5 E.L. Madlevskaya, Geroinya-voitel'nica..., op. cit., p. 1. 
and animation films based on folklore follow the popular tradition of centering the narrative on the hero. ${ }^{6}$

Exceptions are few. In 1922 Marina Tsvetaeva wrote the poem Pereulochki (Moscow Lanes) $)^{7}$ on the basis of the above-mentioned story of Dobrynia and Marinka, where the narrator is the sorceress Marinka, the poetess's namesake. Another case of transferring the narrative focus to the heroine is the animated Soviet film Vasilisa Mikulichna,${ }^{8}$ based on the bylina "Stavr Godinovitch." Vasilisa Mikulichna, wife of the bogatyr Stavr, saves her husband from the knyaz's (Prince's) dungeon, while the rescued bogatyr respectfully watches the brave efforts of his cunning and artful wife. The script for this animated film was written by well-known female writer Victoria Tokareva. In both cases the talented female authors easily transpose heroism from the masculine into the feminine domain. However, I would like to stress once again that in most cases the heroines of the Russian epos are "playing second fiddle" in the long history of publications, studies and media presentations related to bylinas. At the same time, bylina narrators rarely tell stories where the female protagonists are completely in the shadows of the deeds of the bogatyrs.

Systematic studies of variants of both common and rare bylina plots ${ }^{9}$ confirm the fact that the narrators pay a lot of attention to the personality, appearance and agency of epic heroines. By "agency" I mean the capacity of a character or person to be the subject of actions. Moreover, in bylinas the male protagonists tend to become pawns in sophisticated feminine games. For example, in the game of a chess motif of the unfaithful wife Katerina and her lover bogatyr Churila, it is the heroine who sets the gameplay and her feigned weakness in the game makes her victorious in the romantic battle. ${ }^{10}$ The cunning tricks, daring deceptions, bold choices and exceptional physical fortitude of the heroines surprise the singers of the tales themselves, regardless of their gender, so much that sometimes they interrupt their song with

${ }^{6}$ During the Soviet and the post-Soviet periods several dozens of feature and animated films based on the topics of Russian folklore epos have been shot, among them: Dobrynia Nikitich (puppet animated firm, dir. V. Degtyaryov, "Soyuzmultfilm" Studio, 1965); Ilya Muromets and Solovey the Whistler-Robber (picture cartoons, dir. I. Aksenchuk, 1975); Alyosha Popovitch and Tugarin (dir. K. Bronzit, "Melnitsa" Studio, 2004) and the whole bylina cycle of full-length "Melnitsa-Studio" cartoons featuring bogatyrs.

${ }^{7}$ Fairy-tale poem was written in 1922 and was published in 1923 with dedication "To Aleksey Aleksandrovitch Pogayetskiy-Chabrov as a memento of our last Moscow."

${ }^{8}$ Vasilisa Mikulishna (Soyuzmultfilm Studio, 1975, dir. R. Davydov, script: V. Tokareva).

9 All known variants of the recorded plots "Churila Plenkovitch and Katerina" (44 texts), "Mikhailo Potyk" (43 texts), as well as two regional collections of epics of the basins of the Mezen' and Pechora Rivers published in: Russian Folklore Collection. Bylinas, vol. 1: The Pechora Bylinas: North of European Russia, A.A. Gorelov (ed.), St. Petersburg 2001; vol. 2: The Pechora Bylinas: North of European Russia, A.A. Gorelov (ed.), St. Petersburg 2001; vol. 3: The Mezen Bylinas: North of European Russia, A.A. Gorelov (ed.), St. Petersburg 2003; vol. 4: The Mezen Bylinas: North of European Russia, A.A. Gorelov (ed.), St. Petersburg 2004; vol. 5: The Mezen Bylinas: North of European Russia, A.A. Gorelov (ed.), St. Petersburg 2006.

10 The motif of a game of chess appears in the Onega variant of "Churila Plenkovitch and Katerina" bylina (12 texts out of 44 known tests). The bogatyr initiates the game and love affair only in one text out of 12. I would like to express my gratitude to Lilia Petrova for provided data on results of her analysis of this motif on my seminar "Basics of Traditional Text Analysis" (the Philological Faculty of St. Petersburg State University, spring semester of 2017-2018 academic year). 
words in prose of merit or reproach to comment on the deeds and actions of the wives, brides, sorceresses and female warriors. Despite all the efforts taken by the bylina heroines, retribution always falls on them for their willfulness and their desires - the singer often makes a choice only between their agonizing and not-so-painful death/ execution in the finale. ${ }^{11}$ Nevertheless, in the "masculine" universe of the Russian epos a regiment of various females acts either openly or covertly.

Thus, I set for myself several objectives: first of all, I would like to study the system of female characters of the Russian bylinas through the focus of their gender and age status, and, secondly, my aim is to define the modi operandi of epic heroines in the context of the social experience of the narrators (taking as an example the personal biography of one of the bylina performers). As I mentioned above, the last task will be solved with the method of analyses of everyday practices introduced by Michel de Certeau. Following de Certeau's concept, I assume that narrating bylinas - oral poetic stories of the remote past ${ }^{12}$ - serves the task of verbalizing the modi operandi and the way of thinking in real life: "Tales and legends seem to have the same role. They are deployed, like games, in a space outside of and isolated from daily competition, that of the past, the marvelous, the original. In that space can thus be revealed, dressed as gods or heroes, the models of good or bad ruses that can be used every day. Moves, not truths are recounted." 13 The narrator informs his/her audience first about the modi operandi in various circumstances known to him/her, and then about underlying values governing the choice of this or that modus operandi. When I analyze the activities of female characters in the social context I assume that the storytelling is a method of teaching modes and ways of real-life behavior, and that when singing bylinas women and men are rendering their personal experience and knowledge in fictionalized form. To find the way to the personal experience and collective ethos is in fact the ultimate purpose of my study of epic plots. I consider each epic plot as a stimulus to state the individual and common experience of a particular narrator. And here I would like to repeat after Albert Lord: “....in a very real sense every performance is a separate song; for every performance is unique, and every performance bears the signature of its poet singer." 14

My understanding of plot variations is quite similar to formalistic distinction between the storyline and the plot, and it follows the logic of Lev S. Vygotsky, who analyzed the influence of the non-matches between the storyline and the plot on the story's perception by a reader.

11 We have 29 complete variants of "Churila Plenkovitch and Katerina" bylina: in eight variants Permyata, Katerina's husband, cruelly kills Katerina, who was unfaithful to him, without any hesitation or small talk; kills her after she refuses to repent in nine variants; kills her in response to her own request after the killing of her lover in five variants. In four variants Katerina commits suicide. In three variants the wife remains alive: she either gets punished and lectured by the husband or kills the husband or even reproaches the husband for killing her lover. These data are taken from the presentation of N.A. Kurzina Gestures and Motifs of Guilt, Forgiveness and Defiance in "Churila and Katerina' Plot" at the conference "December Proceedings in Memory of N.M. Gerasimova" (December, 2017)

12 Russian bylinas are called starinas by the singers, which mean "tales of old times."

13 M. de Certeau, op. cit., p. 23.

14 A.B. Lord, The Singer of Tales, S. Mitchell, G. Nagy (eds.), Cambridge, MA-London 2000, p. 5. 
Shklovskiy and Tomashevkiy define the fabula as the story's material, i.e. the chain of events of everyday life, which the story is based on, while the plot is a formal development and treatment of this story. [...] Evidently the relations between the material and the form in a story are in fact the relations between the fabula and the plot. If we wish to find out in which direction the poet's story-embodied creativity flows, we should learn by what means and for what tasks the fabula has been processed by the poet and transformed into a given poetic plot. ${ }^{15}$

The bylina singers, just like poets, have been given a certain material (a commonly known sequence of events), but they have been re-telling it in their own way, creating unique personal statement each time. A young singer rendering, for example, the story about Mikhailo Potyk, obediently follows the well-known storyline but puts the emphasis on the hero meeting the heroine and on the "self-matchmaking" of the latter. The married woman telling the same story pays attention to the hardships of marriage and to the bad temper of the bogatyr as a husband. The old singer will by all means inform the audience about the success of the second bogatyr's marriage as compared to the first one. And a not-so-young-any-more bachelor may even shed a few tears over the story about a cheating wife. ${ }^{16}$ The storyline construction may be common for the narrators as members of the same family, village or regional community. The plot realization will vary in accordance with the different narrating competencies and social experiences of the narrator.

Describing the system of female characters of the Russian epos, that is, the material which is common to the singers, I will demonstrate particular cases of interchange between personal experience and plot realization, explicating collective ethos as a system of root causes of modus operandi.

In order to accurately describe the deeds of the Russian epic heroines I would like to stress that researchers define the universe of bylinas as utterly patriarchal. I have already quoted E.L. Madlevskaya, who noted the hero-centered layout of the domain where bylina characters operate. Moreover, if we look at the northern Russian epic story-telling in terms of transmitted ethos, we may come to the same conclusion on patriarchal values prevailing in the Russian epos as Laura Olson and Svetlana Adonyeva did, who studied the relations between patriarchal ethics and special feminine knowledge. "The epic drama confirms not only nationality, but also the patriarchal social system itself, since in its depiction of the hero winning a wife, epic briefly entertains the possibility that the female family line might dominate. The female line does not: the hero inevitably wins over his bride through battle, and patriarchy is validated." $" 17$

It has been already mentioned above that men have been victorious over women within the frames of epic plots and beyond them. Women have been definitely

${ }^{15}$ L. Vygotsky, The Psychology of Art, Cambridge, MA 1971, p. 145.

16 "Vassiliy Dorofeyevitch Shisholov. Lives in Verkhneye Bugayevo Village. Boisterous and perky man of 40-45 years of age. Can hardly make both ends meet as being always tipsy. His family life is ruined and V.D. is constantly complaining about some misfortune shadowing his whole existence. He sang me bylina about Churila and unfaithful wife with a lot of feelings and even with tears in his eyes, probably comparing its content with his own hapless lot," writes N.E. Onchukov about one of the narrators (Severnye skazki. Sbornik N.E. Onchukova, St. Petersburg 1998, vol. 1, p. 167).

${ }^{17}$ L.J. Olson, S. Adonyeva, op. cit., p. 31. 
considered second best in the publishing of bylina records as well as in adapting byli$n a$ plots to new media forms. The axioms of the domination of male world values in the epos have been transferred unchanged from folklore poetics to description, for example, of the dwelling place of the epos. The keynote of collecting bylinas in the first half of the 20th century is the lament for the disappearance of male singers and decline of tradition in the regions where women started singing bylinas. Olson and Adonyeva suggested that the prevalence of bylinas sung by men in the first years of their collection was determined by the patriarchal structure of the community: male folklorists were working among male storytellers. The recording took place at "masculine" places such as coaching inns, steamboats and ferries (compare with description of field work conducted by Milman Parry and Albert Lord). ${ }^{18}$ Olson and Adonyeva are of the opinion that "it is likely that the masculine tradition of singing epics in public was paralleled by a feminine tradition of singing epics within the home." ${ }^{19}$ In fact many female epos singers confessed that before meeting folklore collectors they sang bylinas to their children at home or even when absolutely alone. For example, in 1937 in Petrozavodsk folklorists recorded bylinas sang by Anna Mikhailovna Pashkova. The singer came to the institute ${ }^{20}$ by her own initiative after she had learned from the "old people" in a shop queue that the institute was the place "where they accept bylinas, songs and fairy-tales." 21 The bylinas sung by Anna Mikhailovna exceed or are at the same level in terms of quality and volume to the variants sung by the "stars" of Russian epos - Trofim Ryabinin, Agrafena and Marfa Krykovs. However the singer herself insisted that she had been singing bylinas for herself while alone, and later for her ill son. Her husband when he was alive had not allowed her to sing bylinas, and even prohibited other singers to perform in his presence. ${ }^{22}$

Thus, we can classify the most well-known female characters of the Russian epos into two groups by their age and social status: maidens (marriageable girls and bridesmaids) and married women.

Bridesmaids attracted particular interest of the researches as some of them bore similarities to Valkyries, Willies and Amazons of the western European folklore tradition. As I have already mentioned, the thesis of E.L. Madlevskaya is dedicated to descriptions of female warriors. The author includes in this category Marinka Kaidalovna and Marina Lyuta Groza (Dobrynia and Marinka), ${ }^{23}$ Marya the White Swan

${ }^{18}$ M. Parry described in details the interactions with Muslim singers in coffee-houses and how "to keep them in spirits with wine, rakija, Turkish coffee, and cigarettes. On a fairly lavish entertainment depends in no small measure the prestige of the recorder and the willingness of the singers to give their best efforts. The material for the entertainment is itself not costly, coffee, wine, or rakija costing only a few cents a glass; but it must be given to many in large quantities" (M. Parry, Project for a Study of Yugoslavian Popular Oral Poetry, cit. by: A.B. Lord, op. cit., pp. 8-9). The described treaties leave no doubt about the gender of the singers.

${ }^{19}$ L.J. Olson, S. Adonyeva, op. cit., p. 32.

${ }^{20}$ Karelian and Finnish Scientific and Research Institute of Culture (1937-1946, Petrozavodsk). Today - Karelian Scientific Center of the Russian Academy of Sciences.

${ }^{21}$ Byliny Pudozhskogo kra'ia, A. M. Astakhova (ed.), Petrozavodsk 1941, p. 461.

${ }^{22}$ Ibidem.

${ }^{23}$ The traditional titles of bylinas used in folklore studies are presented in brackets. Variants of the bylinas have been analyzed as published in Mezen' and Pechora parts of Russian Folklore Collection. Bylinas unless otherwise specified. 
(Mikhailo Potyk), Zlatygorka (Ilya Muromets and the Falconer), and Nastassya (Dunai and Nepra). Among bylina girls of marriageable age are also Zabava Putyatishna (Solovey Budimirovitch), Chavitza Chusavitzna (Khoten Bludovitch), Nastassya Vikulichna (Dobrynia and Nastassya), sister of Petrovichi Sbrodobitchi (Alyosha and the Sister of Petrovichi Sbrodobitchi). All these girls have plenty of agency, especially with respect to matchmaking and sexual relations. They are the first to offer marriage/ friendship to the bogatyrs, demonstrate their strength in fighting with the bogatyrs in the "open field," reject unworthy suitors without any parental advice, have sexual relations before marriage, and show imprudent curiosity while visiting the bogatyr's house unaccompanied by any nannies or custodians.

Let us study a particular bylina text. The considered variant of "Mikhailo Potyk" was recorded from the mentioned Anna Mikhailovna Pashkova in February, 1939 by E.S. Shoymer in Petrozavodsk and published in 1941 in the volume Bylinas of Pudozh Region. This bylina consists of 1,143 verses, making it the longest version of this story. The composition is faultless - all the motifs are repeated in three elegant variations and are accentuated by breathtaking details. In short, the beginning of this variant is as follows: the bogatyr Mikhailo Potyk is commissioned by his knyaz (the Prince of Kiev) to the neighboring country "to increase the lands of the Holy Russia." When Mikhailo arrives at the destination on the back of his mighty horse, he decides not to hurry with his mission but to have a rest in his tent. The daughter of the neighboring country's tsar, Marya the White Swan, after tracking Mikhailo's tent through a telescope (!) asks her father to let her walk for three years (!) and obtains his permission surprisingly easily. ${ }^{24} \mathrm{After}$ that Marya shrugs off her nannies and lady companions and approaches Mikhailo alone, asking him to take her into friendship. Instead of friendship the hero offers marriage. In response to this the White Swan sets the condition that the surviving spouse shall lie alive in the coffin of the spouse who dies first. So Marya in her maidenhood is full of initiative: she is strong-willed and does not hesitate to inform her father and her suitor about her wishes and her terms.

Generally, epic bridesmaids easily commit actions which are taboo or even unthinkable in the Russian traditional peasant community. One transgression follows another: self-matchmaking, offering friendship to a fellow, open pre-marital sexual relations, and visiting the bachelor's house on her own. In the storylines of the bylinas the maiden heroines behave in a way which would have been absolutely inadmissible for girls of the same age and status in real life. ${ }^{25}$ However the openness of bylina brides-

${ }^{24}$ You are the loving daughter, Marya the White Swan by name,

For a walk you went, for a long walk, three years long,

You have never brought any evil fame to your father,

Walk away, Marya the White Swan, into open field,

But take nannies and nurses with you,

And your maidservants, oh so faithful, bring along (Byliny Pudozhskogo kra'ia ..., op. cit., p. 134).

${ }^{25}$ The scope of this article does not permit further details about rules of behavior for the girls of marriageable age in the traditional Russian culture. For additional information about transgression behavioral scenarios, reputational risks as well as gender and age conventions of this social stratum see the following publications based on field studies conducted by St. Petersburg State University: A.A. Borisova, Rasskazy o "porchenyh devkah" kak instrument social'nogo kontrol'ia, [in:] Kommunikativnye konvencii i social'nye scenarii. Filologicheskij praktikum, S.B. Adon'eva, S.O. Kupriyanova (eds.), 
maids in stating their wishes is based on a certain social background. Their liberty is an imaginary continuity in the bylina universe of "the girls" power" as a relative freedom enjoyed by unmarried maidens in the peasant society. The bridesmaid's lamentations on the maiden's "beauty" and "will" at the wedding ceremony is not merely a figure of speech but regret for actual modification of behavioral scenarios. Young unmarried men and women in Russian villages have broader economic liberties (the money they have earned is usually spent on fine clothes and dowry) and freedom of entertainment as compared with other family members. The manifestations of the freedom of youth have differed, but its degree has remained roughly the same. The above-mentioned singer A.M. Pashkova recalls her maiden years as the best time of her life:

And I was dressed very well: I had a string of pearls, damask pinafores and brocade jackets. I'd not even turned sixteen when a marriage was proposed to me. If my current suitor has asked me at that time, probably I would have said 'yes,' but they were people from another volost' (district). I lived happily as a maiden till I was twenty." ${ }^{26}$

Being a bridesmaid of no slender means, Anna was very particular about her future husband, knowing her emotional preferences exactly, and she was in no hurry to accept proposals. Her family's prosperity came to an end after a village fire and her status in the matrimonial market declined, so she was under pressure to make a decision about marriage. Unfortunately under such circumstances she had to forsake her emotional preferences, welfare, and habitual leisure time:

As soon as I turned twenty the whole village of ours was burnt to the earth in April. A lot of my beautiful clothes were taken by the fire. It was a total loss. I reckoned this way and that and accepted a proposal I got after the disaster. People said he was richer than me, but I had never seen his house. And he was eight years my senior. It turned out that his family consists of a dozen people, all living in one izba (peasant log house) with a hearth furnace and no chimney. That was my ill fate. I have cried my heart out, but they never let me visit my family, though I missed them so much. I became very thin from my troubles and then was with child. At home we have Aunt Kseniya who knew a lot of bylinas, old songs and fairy-tales. No-one in my new family sang any verses, bylinas or anything of the sort! ${ }^{27}$

The words and tone of Anna Mikhailovna sound very similar to recollections of the first years of marriage of other peasant women and to wedding lamentations. The relative freedom of behavior of unmarried girls in the Russian traditional village is replaced after the wedding by strict mending in almost all matters of the mother-in-law, the father-in-law, and the husband. The question is, how have such changes in the rules of behavior for married women been implemented in bylina poetics?

Married heroines form the biggest female gender and age stratum in Russian epics. Many bogatyrs combine military service in the knyaz's troops with family life. Dobrynia is married to Nastassya Vikulichna/Likhodeyevna (Dobrynia and Nastassya),

St. Petersburg 2014, pp. 221-229; A.S. Karetnikova, Brak "samohodkoj," [in:] Kommunikativnye konvencii..., op. cit., pp. 74-91; E.S. Mamaeva, Zhiznennyj scenarij sovetskoj zhenshchiny - "bojkaya," [in:] Kommunikativnye konvencii..., op. cit., pp. 100-109.

${ }^{26}$ Byliny Pudozhskogo kra'ia..., op. cit., p. 61.

27 Ibidem. 
Mikhailo Potyk is married to Marya the White Swan (Mikhailo Potyk), and Stavr is married to Vasilisa Mikulichna (Stavr Godinovitch). Peremyata, Katerina's husband, has to deal with his wife's affair with the bogatyr Churila Plenkovitch (Churila Plenkovitch and Katerina). Knyaz (Prince) Vladimir rules his state together with his wife knyaginya Apraxeiya, who sometimes provides her husband with sage advice and sometimes falls in love with wandering minstrels (Vasilisa Mikulichna, Forty Minstrels). Dyuk Stepanovitch marries Ovdotyushka Grigoryovna (Dyuk Stepanovitch). The wives of bogatyrs, knyazes and ordinary townsmen are as active as the bridesmaids, but their activity is of another kind. In order to save their husbands or leave them or have a love affair, the married women have to be cunning and conceal their true purposes. Michel de Certeau in The Practice of Everyday Life distinguishes between the strategic and the tactic mode of actions in everyday life. According to de Certeau, strategic behavior is typical for protagonists in a dominant position. The actor, being a strategist, openly advocates his desires and interests; his agency is supported by the social order and self-assurance of his own truth. That is the modus operandi of the girls of marriageable age and of heroic bridesmaids in Russian bylinas. Contrary to the strategic mode of behavior, the tactic mode is defined by a lack of authoritativeness in the actor's position.

A practice of the order constructed by others redistributes its space; it creates at least a certain play in that order, a space for maneuvers of unequal forces and for utopian points of reference. [...] Innumerable ways of playing and foiling the other's game that is, the space instituted by others, characterize the subtle, stubborn, resistant activity of groups which, since they lack their own space, have to get along in a network of already established forces and representations. People have to make do with what they have. In these combatants' stratagems, there is a certain art of placing one's blows, a pleasure in getting around the rules of a constraining space. ${ }^{28}$

Let us study the transfer from strategic to tactic behavior in the activities of Marya the White Swan of "Mikhailo Potyk" bylina, narrated by A.M. Pashkova. As the story evolves (the beginning of which has been recited above), Mikhailo and Marya get married in Kiev. After a short marriage with the bogatyr the heroine is dead. In compliance with the marriage contract she is buried along with her living husband. In the grave Mikhailo fights with an earth serpent, defeats it and makes the serpent resuscitate Marya. Bogatyr's friends take both spouses from the grave after receiving a prearranged signal, and Marya enjoys the great fame of an immortal person. Attracted by her fame and continuous absence of her husband, the suitors inform Marya about her husband's death, which they have allegedly witnessed. One of the suitors promises her the most beneficial terms of a new marriage:

With Mikhailo you lived as a washerwoman,

Just a washerwoman and a charwoman,

If you marry me, Marya the White Swan,

Marry me, Vassiliy Okulov,

You will be my tsaritsa. ${ }^{29}$

\footnotetext{
${ }^{28}$ M. de Certeau, op. cit., p. 18.

${ }_{29}$ Byliny Pudozhskogo kra'ia..., op. cit., p. 145.
} 
Marya gives her consent to the new marriage. After that, the interests of Marya and Mikhailo become antagonistic. The bogatyr, being "more than alive," searches for his departed wife three times, and Marya practices her growing insidiousness three times. Every time she meets her ex-husband, who chases her with her new spouse without showing any anger. And three times Marya poisons him with magic potion - the wine of oblivion. In the first case she abandons the sleeping bogatyr in an open field, in the second she envelops him in a grey stone, and in the third she nails his unconscious body to the outer wall of her new kingdom. Twice the bogatyr is rescued by his friends. We can see that Marya has completely changed her behavioral mode. When she was a maiden, she expressly stated her desires and intentions to both her father and her bridegroom. The married Marya never let her ex-husband know about her decisions or wishes. She meets him with a new serving of the "wine of oblivion." In the first episode she pretends to be happy to meet her ex-husband, in the second episode she complains of her subservient status, and in the third episode she welcomes him with false hospitality. The success of the trickster tactics of Marya the White Swan is so obvious that her feigned lamentations have even convinced the bylina scholar Aleksey V. Markov. In his article The Private Life Features of Russian Bylinas he quotes Marya's complaints in his description of the deprived status of Russian women: "the slave-like position of a wife as a captive is accurately communicated by the words from the mouth of Potyk's wife, the queen":

We go where we are taken,

We drive where we are driven. ${ }^{30}$

It should be kept in mind that in these particular circumstances Marya deceives her husband (as well as the scholar), pretending to be a hostage of her subordinate position. We can see that Marya actively promotes her interests but uses "the weapons of the weak" ${ }^{31}$ for this purpose. She easily cheats and deceives Potyk, telling him what he wants to hear and is able to perceive. Both Mikhailo Potyk and A.V. Markov fall for her lies in good faith. The wife knows that her former husband will not refuse to take a glass of wine, will not be able to resist the (feigned) happiness of meeting each other, (pretended) weakness and (false) hospitality. Being a sorceress with the fame of immortality, Marya acts as a married woman - she strives to fulfill her wishes subtly and covertly. My words about the "trickster" behavior of married women "inside" and "outside" the epos universe could be considered farfetched, but several details in the personal biography of the singer Anna Mikhailovna Pashkova provide sufficient evidence. Her choice of husband was dictated by strained circumstances: she did not know the man personally before the wedding and

30 A.V. Markov, Bytovye cherty russkih bylin, "Etnograficheskoe obozrenie" 1903, no. 4, p. 2.

31 James Scott and Michel de Certeau speak about the "tactics" and "weapons of the weak" as the means of implicit confrontation with the authority and power of those in the dominant position. Researchers have added to "the weapons of the weak" not only minor sabotage, theft, and property damage, but also gossiping, tale-bearing, sharing funny stories about the authorities and fairy-tales where the initially "weak" character wins in the end. Thus, the trickster's tales are considered by the researches to belong to "the weapons of the weak" arsenal. (J. Scott, op. cit.; M. de Certeau, op. cit.). 
was not aware of his family environment. She grew up in a family where she was dressed up and cosseted as a future bridesmaid. Also her relatives were ardent singers and gave shelter to minstrel strangers: "I've heard bylinas since my childhood from my aunt [...] from an old beggar... who knew plenty of them." Anna's in-laws were quite different: they did not sing, worked hard and "my husband did not like bylinas and never allowed them to be sung." That is why Anna Mikhailovna heard no epics from the well-known narrator Fiodor A. Konashkov, with whom they went fishing together: "my husband never allowed him to utter a word." 32 Anna Mikhailovna was not in a position to sing bylinas when her husband was alive, but she kept a huge epic repertoire in her memory. Holding a particular place in the family hierarchy of her inlaws, Anna Mikhailovna could hardly think about any transgressions. She indulged in her hobby - singing - only when no one was around to hear her.

The biography of another outstanding folklore singer, Irina Andreyevna Fedosova, has many similar features with respect to marriage, despite the 40 -year age difference (Fedosova was born in 1827, while Pashkova in 1866). After the death of her first husband, Irina Andreyevna had to marry again at the age of 36 . Her second husband was a fine woodworker but a heavy drinker. In a well-known funeral lamentation Wailing for the Drunken Head Fedosova discloses the feelings of the drinker's widow "who is torn by pity for the man, anger, the wish to keep him and the understanding that she has no power over his habits. ${ }^{" 33}$ The lamentation starts with a description of a holiday morning. The wife is doing housework and cooking a festive meal; she puts on her best clothes anticipating a trip with her husband to the fair, but her husband forbids her to accompany him. After his departure, the wife sits by the window, watches the neighboring women leaving for the festival with their husbands, cries and in despair prays for her husband's hasty death. A day later the body of her husband, frozen to death while drunk, is brought home. Impotence and despair mark the emotional keynote of her wailing, exposing the tragic aspect of the position of the weak.

In situations of overpowering domestic violence created by a drinking husband or a petty family tyrant the wives prefer not to be engaged in active confrontation. They use the everyday tactics of the weak - silent protest, feigned submission, and magic lore. In her wailing I.A. Fedosova tells about feelings and reactions, too familiar to her, speaking on behalf of the widow of a drunkard husband. Demonstrating feigned submission to violence, she seeks liberation from the tyrant by appealing to metaphysical forces. A.M. Pashkova preferred to sing bylinas in secret despite her husband's ban but kept the legacy of her epics in her memory through such declamation to herself. Marya the White Swan as a character of the bylina narrative demonstrating submissiveness (feigned happiness and false weakness) applies magical instruments of resistance. Madlevskaya in her thesis, already quoted above, writes: "In the plots of 'Mikhailo Potyk' and 'Dobrynia and Marinka' the decisive attribute of the heroines is possession of magical lore and skills. The relations between masculine and feminine

32 Byliny Pudozhskogo kra'ia..., op. cit., p. 461.

${ }^{33}$ K.V. Chistov, Comments to "Plach po up'yanslivoj golovushke," [in:] Prichitaniya Severnogo kra'ia, sobrannye E.V. Barsovym, vol. 1: Pohoronnye prichitaniya, B.E. Chistova, K.V. Chistov (eds.), St. Petersburg 1997, p. 377. 
characters develop as the battle between physically able and strong Russian bogatyr and the heroine endued with another kind of power - that of magic." 34

A.M. Pashkova, after losing her husband and marital property in misfortunes of the Soviet collectivization of 1933, moved from a village to her daughter's household in the city. Only then she was able to demonstrate her epic singer's talent to those who could value it. Such a change of fortune was actually a blessing in disguise, although I could not imagine Anna Mikhailovna felt "blessed." In fact the dramatic twists and turns of the history of peasantry in the 20th century gave peasant women the right to speak. The destruction of the class of men as heads of the household made the voices of their wives heard. I think neither men nor women wished to pay such a price for the right of voice transferred to the latter. The Bylina about Mikhailo Potyk sung by A.M. Pashkova represents the whole arsenal of cunning feminine tactics of feigned submission to the husband's power. It is very typical that Marya the trickster is brought to justice by another woman - the daughter of the second husband of Marya the White Swan, who manages to decipher her rival's tactics. The step-daughter of Marya the White Swan finds the wounded Mikhailo by the kingdom walls. She cures him and teaches him how to overcome Marya: first of all, he should not drink the cup with "the wine of oblivion." Mikhailo follows the advice and puts Marya the White Swan to a terrible death. His lifesaver greets the winner with a low bow and receives a marriage proposal which she accepts immediately. This means that the bogatyr hardly understands that the new wife has again outwitted him.

We see that everyday tactics in the real family life of the singer and the tactics of the female character in bylina can be defined as isomorphism. Within the patriarchal universe the talented singer narrates a long bylina about Mikhailo Potyk's wife communicating her modus operandi in the family, where husband has the public authority in its entirety. The collective ethos of patriarchal family values provides the wives with an arsenal of "the weapons of the weak." This arsenal allows them to preserve desires, intentions and feelings. Eventually the singer tells two tales: one is about courageous love of the bridesmaid, and the other is about an active wife whose tricks are doomed to defeat.

\section{References}

Borisova A.A., Rasskazy o "porchenyh devkah" kak instrument social'nogo kontrol'ia, [in:] Kommunikativnye konvencii i social'nye scenarii. Filologicheskij praktikum, S.B. Adon'eva, S.O. Kupriyanova (eds.), St. Petersburg 2014, pp. 221-229.

Byliny Pudozhskogo kra'ia, A.M. Astakhova (ed.), Petrozavodsk 1941.

Certeau M. de., The Practice of Everyday Life, Berkeley 1984.

Chistov K.V., Comments to "Plach po up'yanslivoj golovushke," [in:] Prichitaniya Severnogo kra'ia, sobrannye E.V. Barsovym, vol. 1: Pohoronnye prichitaniya, B.E. Chistova, K.V. Chistov (eds.), St. Petersburg 1997, pp. 377-378.

${ }^{34}$ E.L. Madlevskaya, Geroinya-voitel'nica..., op. cit., p. 27. 
Karetnikova A.S., Brak "samohodkoj," [in:] Kommunikativnye konvencii i social'nye scenarii. Filologicheskij praktikum, S.B. Adon'eva, S.O. Kupriyanova (eds.), St. Petersburg 2014, pp. 74-91.

Lord A.B., The Singer of Tles, S. Mitchell, G. Nagy (eds.), http://nrs.harvard.edu/urn3:hul. ebook:CHS_LordA.The_Singer_of_Tales.2000 [access: 19.02.2019].

Madlevskaya E.L., Geroinya-voitel'nica v russkih bylinah. Nastas'ya (syuzhet "Dunaj i Nepra"), http://www.folk.ru/Research/Conf_2002/madlevskaya.php?rubr=Research-conf [access: 19.02. 2019].

Madlevskaya E.L., Geroinya-voitel'nica v ehpicheskih zhanrah russkogo fol'klora [avtoreferat dissertacii kandidata filologicheskih nauk, St. Petersburg 2000], manuscript in Russian National Library.

Mamaeva E.S., Zhiznennyj scenarij sovetskoj zhenshchiny - "bojkaya," [in:] Kommunikativnye konvencii i social'nye scenarii. Filologicheskij praktikum, S.B. Adon'eva, S.O. Kupriyanova (eds.), St. Petersburg 2014, pp. 100-109.

Markov A.V., Bytovye cherty russkih bylin, "Etnograficheskoe obozrenie" 1903, no. 4, pp. 1-27.

Novik E.S., Struktura skazochnogo tryuka, http://www.ruthenia.ru/folklore/novik5.htm [access: 19.02.2019].

Olson L.J., Adonyeva S., The Worlds of Russian Village Women: Tradition, Transgression, Compromise, Madison 2013.

Pushkareva N.L., Chastnaya zhizn' russkoj zhenshchiny: nevesta, zhena, lyubovnica (X-nachalo XIX v.), Moscow 1997.

Scott J., Weapons of the Weak: Everyday Forms of Peasant Resistance, New Haven 1985.

Severnye skazki. Sbornik N.E. Onchukova, St. Petersburg 1998, vol. 1.

Vygotsky L., The Psychology of Art, Cambridge, MA 1971. 
